\title{
The New Vision in the Creation of Arabic Novels in the 2000s
}

\author{
Eva Farhah ${ }^{\mathbf{1}}$ Reza Sukma Nugraha ${ }^{2}$ Abdul Malik ${ }^{3}$ \\ \{1evafarhah@staff.uns.ac.id, ${ }^{2}$ reza.sn@staff.uns.ac.id, ${ }^{3}$ abdul_malik@staff.uns.ac.id\} \\ 1,2,3Arabic Language and Letters Department, Faculty of Cultural Sciences, \\ Sebelas Maret University
}

\begin{abstract}
This study aimed at revealing the tendency or new vision of Arabic authors in creating literary works. Literary works published in modern times (in the 2000s) are the novels that reveal about the existing social reality in society. The creation of these novels is, certainly motivated by the occurring events in the midst of society. The authors' life background certainly serves a significant role in producing novels which carry the author's vision. To reveal the tendency of the author's vision, a descriptive and qualitative method was used and implemented the sociology of literature that focuses on examining the author's sociology and literary works. The results revealed that the author's new vision was reflected in the novels under study in which the author's personal experience was strongly affected by the social realities he faced, as the vision was manifested in the novel "Banat Ar-Riyad" (2005), "Yauman Ma ... Kuntu Islamiyyan" (2012 ). Thus, these novels are typically classified as biographical novels.
\end{abstract}

Keywords: New vision, Creation, Arabic novels, Sociology of literature

\section{Introduction}

Literary work is a "possible world", for it was born in response to modernity. Literature and modernity offer a struggle between the old and the new worlds [1]. Such is the case of the presence of Arabic novels in the 2000s. Many of the created Arabic novels in the 2000s were deal with modernity. This modernity is represented by the current Saudi Arabian girls' attitudes whose lifestyleswere told to be more advanced compared to girls living in ancient times. The Arab girls of today incline towardsfollowing the modern times development. They use electronic media (internet), mobile phones, get involved in higher education in universities, live in free relationships between members of the opposite sex, and get out of the house freely without any companion muhrim as illustrated in the novel "Banat ar-Riyadh" ( 2005) The work of King Abdullah Al-Sanea [2]; [3]; [4]. This novel was not only created without any connection between the background of the author and the social reality he experienced. This novel is hereinafter referred to as the first novel [N1]. Another tendency that appears in the novel "Yauman Ma ... KuntuIslamiyyan" (2012) by Ahmad Abu Kholil is a personal experience of a person (Author) in his struggle through changing attitudes ofhis religious side [5]. This novel is hereinafter referred to as the second novel [N2]. This novel describes the following details; the ways a group of religious sect persistently instills doctrines of their 
religious teachings, the routines of certain religious groups in continuously instillingtheir doctrines to children and adults, until finally the author determines his attitude to be in a neutral position in accordance with text and contextual understanding, Islamic Shari'a teaching, in a way not to harm other religious groups.

Among the researches on [N1] and [N2] have been previously conducted by researchers in 2011, 2012, 2013 to 2018, a studyinitially conducted by Ahmad Sidiq (2011) entitled "AdDalalah Al-Isyariyah fi Tafkik Al-Abuyah Al-'Arabiyyah Banat Ar-Riyadh li Raja' Abdullah Ash-Shani ' $i$ ". The results of his research revealed an indexical relationship between Arabic culture and the charactersphenomenon in the novel of Banatu' $r$-Riyadh. The subsequent study was conducted by Intan Siti Aisyah (2011) in her paper entitled "Konflik Batin Tokoh pada Novel The Girls of Riyadh Karya Raja Al Sanea: Kajian Psikologi Sastra Sigmund Freud”. Her results of study concernsthe psychological aspects reflected in the novelThe Girls of Riyadh dominated by the id aspect and the figure who dominates all aspects, id, ego and superego are Qamrah. In the following year, Syahril's (2012) study entitled "Arena Produksi Kultural dan Kekerasan Simbolik Analisis terhadap Novel Banatu 'r-Riyadh Karya Raja' AshShani 'i: Perspektif Sosiologi Pierre Bourdieu’. Her study discusses the arena of cultural production and symbolic violence in Banatu'r-Riyadh novel which has implications for symbolic violence. Risna Rianti Sari's (2013) in her paper entitled "Riyadh fi Riwayati Banati li Raja' Ash-Shani ' $i$ : Dirasati Tahliliyati Ijtima 'iyyah'. The results of this study are in the form of a description of people's sosial life in Riyadh both in terms of culture, tradition, problems faced by the people of Riyadh and the interaction between men and women in Riyadh. The [N2] was studied earlier by Nur Hidayah in 2018 in his paper entitled " $A l$ Wasathiyyah al-Islamiyyah fi Riwayati Yauman Ma Kuntu Islamiyyan”. Her study discussed about al-wasathiyyah al-Islamiyyah which is claimed as a balance in all aspects of Islamic teachings, both ways of thinking or behaving in Islam. Although there have been studies of [N1] and [N2], these studies have not been able to answer the problems discussed in this study. Therefore, another significant aspect of this author's new vision needs to be undertaken.

These two novels, [N1] and [N2] were produced in modern times, precisely in 2005 and 2012. These years were the periods where in major places of the Arab world there were on going dynamic social changes. In Saudi Arabia, the social conditions of the people are progressing and typical competitive people in pursue of a prosperous life. Whereas in the other Arab world, especially among the countries which joined the "Arab Spring", i.e., Egypt is a country where the people's social conditions are in a great demand, riots, and group movements oriented seeking for life change towards prosperity. There are compartmentalized social conditions due to the existing political conditions, where religious movements would jointly participate in contributing to achieve their group's ideals lives [6]. By this social background, the two authors [N1] and [N2] gave birth to literary works with their respective visions reflected in their literary works. This is where the author's vision will be known in each of his works. Thus, this study explicates its benefits, which are to provide new insights and expand the knowledgeof Indonesian authors [7]; [8]. The new vision of Arabic writers can be used as a mirror for Indonesian literary authors. The results of this study can also be used as a reference or review material for other researchers in the same interests, therefore that scientific dynamics and literary studies can well-developed. 


\section{Research Method}

To reveal the tendency of the author's vision, a descriptive and qualitative method was used. This method can be understood as a way of working in a study by finding facts with the right interpretation [9]. Thus, the steps worked are formulating the problem, determine research objectives, determining the scope of research, formulating a conceptual framework by determining the sociology of the author and the sociology of literary works as a basis for analysis, exploring the sources of literature so that this research is objective and quality, collecting data to be analyzed, classifing data, then analyzing the data by providing an interpretation of the data that is determined, and finally, determining conclusions from the results of research after testing hypotheses [10]; [11].

\section{Results And Discussion}

\subsection{The Sociology of The Author and Literature Analysis of "Banat Ar-Riyadh" Work (2005)}

Beginning with the description on sociology of the author, then it was continued with sociology of literary works, the work "Banat Ar-Riyadh" (2005) was analyzed to find and express the new vision of King Abdullah Al-Senia . King Abdullah Al-Senia was a student of the Medicine Faculty at King Saud University in 2005. Through this work, he became famous. The work [N1] was first published in Lebanon in 2005 and was published the second time in the United Kingdom in 2007. This work received multiple reviews from various readers, until finally it was awarded the Dublin Literay Award in 2009 (2018). Based on the author's social description, it is traceable that King Abdullah Al-Senia is a person who comes from a family withmiddle to upper level social life. This can be seen from the level of education the author reached, a graduate fromthe medical faculty at King Saud University. In addition, in his association, King Abdullah Al-Senia is a teenager who was friendly and sociable to teenagers of his age. He is a typicalintrovert person. Hischarming attitudes in making friends made him a trusted person by his teenage friends in accommodating all complaints, thoughts, frustrations, happiness and conflicts experienced by 4 (four) friends.

In the process of its creation, [N1] was produced through the support of figures who subsequently appeared in the work. These figures are pinned on different personalities as can be seen in the chart below:

\begin{tabular}{|c|c|c|c|c|}
\hline $\begin{array}{l}\text { Figure } \\
\text { Temperament }\end{array}$ & $\begin{array}{l}\text { Qamrah } \\
\text { Al- } \\
\text { Qashmajiy }\end{array}$ & $\begin{array}{l}\text { Sadim } \\
\text { Al-Charimliy }\end{array}$ & LumeisJadawiy & $\begin{array}{l}\text { Michelle } \\
\text { Al-'Abdurrachman }\end{array}$ \\
\hline Melancholy & $\begin{array}{l}\text { 1. Religious } \\
\text { 2. Literature } \\
\text { 3. Enthusiasts } \\
\text { 4. Obedient } \\
\text { 5. Romantic } \\
\text { 6. Liars } \\
\text { 7. Be sincere }\end{array}$ & $\mathrm{X}$ & $\mathrm{X}$ & $\mathrm{X}$ \\
\hline Choleric & $\mathrm{X}$ & $\begin{array}{l}\text { 1. Caring } \\
\text { 2. Careful }\end{array}$ & $\mathrm{X}$ & $\mathrm{X}$ \\
\hline
\end{tabular}




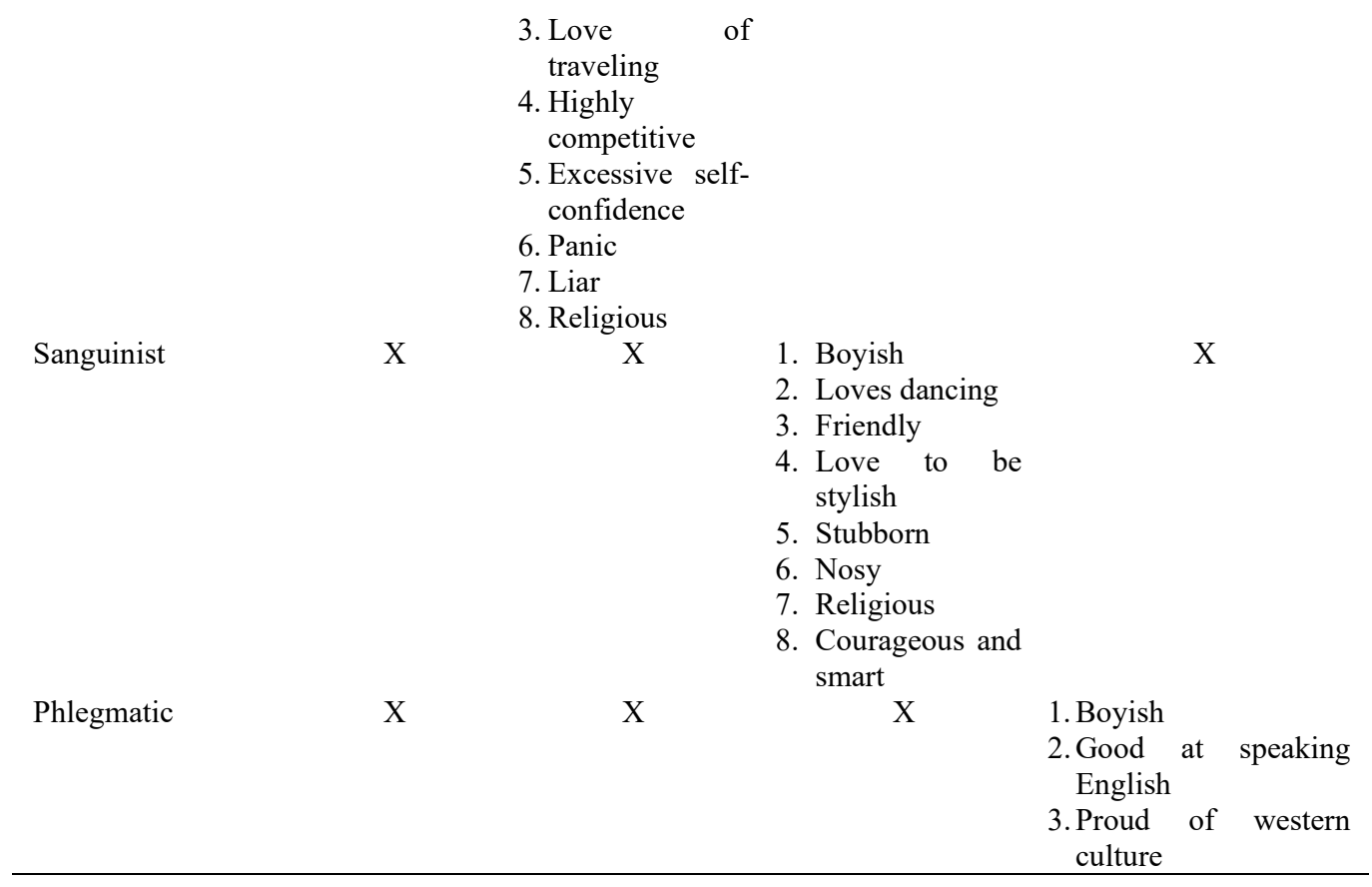

Each character represents social class of theirsociety. Here is, it is quite clear that [N1] is a mirror of people living in Riyadh. Having analyzed from the production process and authorship perspectives, [N1] was produced realistically according to the experiencesundergone by the four figures as representatives of the social groups of Riyadh society. [N1] This was published both in Lebanon (2005) and in England (2007). That is, this work [N1] received a good response from the reading society. [N1] This also received a critical and opposing response from one other community group. Even so, [N1] was finally awarded the Dublin Literay Award in 2009. The results of the study on [N1] revealed that the author's new vision is to portray the image of his society, especially in terms of the women's gender, exploring criticism of between the men and women traditions, and arranged marriages determined by the family. Thus, the new vision highlighted and voiced by the author is to make humans more humane, certainly those of which in accordance with the teachings of religious beliefs and help people set their free from the constraints of harmful traditions.

3.2 The Sociology of The Author and Literature Work Analysis on"Yauman Ma... Kuntu Islamiyyan" (2012)

[N2] (2012) is the Ahmad Abu Khalil's work. He is one of the descendants of a family that follows the teachings of Islam with a particular stream or congregation. He was educated Islamically by both his parents and the environment. In each sub-heading [N2] as was described in detail, such as the name of the elementary school "Asy-Syubban Al-Muslimun", "Bita' Rabbina", "Ikhwanul-Muslimin", "Afrachun-Nada" and others. The author describes each event he and family had experienced. [N2] in general describes the change in religious attitudes that the figures had experienced. The family background of the writer as an adherent of the Muslim Brotherhood has educated him a lot to become a devout young man of religion. However, religious life is disrupted by political conditions. Egypt, specifically the Zaqaziq 
region, is the basis of the Muslim Brotherhood. The education system held in the region is also oriented to the teachings of the Muslim Brotherhood. The great thinkers who are the pride and the Mecca are Hasan Al-Banna and Sayid Quthb. However, the author and his family did not always join the Muslim Brotherhood because of the uncertain political conditions in Egypt at the time. In 2010, 2011 and 2012 Egypt was in a state of quitestrongly driven by political conflict. Between political groups suspect and disagree each other. This is the reason why the author and his family chose not to leave the Muslim Brotherhood and refused to sjoin in any politics in their country, for it is seen as more reassuring for his life. The results of the study of [N2] show that a good society is those who intelligently see and study the teachings of religion and the state. This formed a merciful religious community for all the worlds. This biographical story was written as an author's experience while undergoing the Muslim Brotherhood. The change in religious attitude is well explored without harming the Muslim Brotherhood. Therefore, the author's new vision here is to invite readers and the public to embrace the teachings of the true religion and rahmatanlil'alamin.

\subsection{The Difference on The Visions of "Banat Riyadh" (2005), "Yauman Ma...Kuntu Islamiyyan" (2012) Fromits Succeeding Modern Novels}

Another literary work which is compatibly comparison is the work of an author named Najib Machfoudz. Najib Machfoudz is the author of the novel "Layali Alfu Lailah wa Lailah" [12], hereinafter referred to as [N3]. Indirectly, this work is sort of a continuation of the story "Alfu Lailah wa Lailah". That is, among the events experienced by the main character Raja Syahrayar (1), which adversely affected the society and its environment (2), Syahrazad over came Syahrayar's problems, until King Syahrazad returned to show a calm personality - this is the end of the story "Alfu Lailah waLailah"- (3), the publication of good news in the form of King Syahrayar's decision to keep Syahrazad a live and make her his wife and queen. Thus, the impact is that the community rejoices to welcome the good news and make Syahrazad an example for women (4), the reality of life between rulers and society (6) the good and bad of humans occur based on faith (ma'rifat) to the teachings of their religion and instructions (hidayah) from their Lord - the end of the story "Layali Alfu Lailah wa Lailah" -. Thus Najib Machfouz indirectly reproduces the hypogramwork and makes the work of transformation intact and complete, while maintaining its Arabic tradition.

In summary, this work contains 17 (seventeen) sub-headings, each of which concerns religious, political, and reality messages of the society's lives, partly it comes out of the author's criticism against the rulers who lived in his time. As narrated in his original work; Syahrayar is represented as animage of a dictatorial ruler, authoritarian, and only loves himself. As for Syahrazad, it is a symbol of good humans who sacrifice themselves to save the girls who would be killed by Syahrayar. In addition, other figures were also presented, such as the Shaykh, the dirty bureaucrats, the crafty businessmen, and so on, each of which reflects implications and explicit meaning. In other words, this work is symbolic and realistic [13].

This study concludes that thenovel concernssocial criticism against the government whichmisusedits power to seize people's rights, persecuted the society and as a means to enrich those politically involvedamidst the complexity of people's lives. This novel categorically neither belongs to novel nor biographical work as [N1] and [N2]. For [N3] tends to describe the author'ssocial condition of the society and his criticis magainst the upper class people's lifes tyles or against the government officials for their faults in carrying out the mandate. 


\section{Conclusion}

This paper has shown that, [N1], [N2] and [N3] are typical modern Arabic novels published in the 2000s $(2005,2012,2014)$. The novels that carry the authors' vision are in accordance with the social reality theyconfront. In terms of the types, [N1] and [N2] works are the typical biographical novels, while [N3] is a realistic symbolic novel. The [N1] and [N2] described in detail and clear circumstances, settings, figures and characterizations in addition to events experienced by the author(s). Whereas in [N3], the author tends to symbolically disguise the objects through symbols in each story, since the story is about a reflection of the society he observed. Thus, the new vision of these authors lays on the reflections of events experienced by the authors them selves and those closest to them, as well as reflectionfor social conditions of their society through symbols narrated in their works.

\section{References}

[1] Eco, Umberto, The Limits of Interpretation. Bloomington-Indianapolis: Indiana University Press, 1994.

[2] Ash-Shani'i, Raja'. The Girls of Riyadh. Jakarta Selatan: Ufuk Publishing House, 2007.

[3] Ash-Shani'i, Raja'. Banatu'r-Riyadh. Beirut: Daru's-Saqi, 2005.

[4] Raja, Al-Sanea., On Line. Available: https://en.wikipedia.og, 2018.

[5] Khalil, Ahmad Abu, Yauman Ma ...Kuntu Islamiyyan. Dar Dawwin, Kairo, 2012.

[6] Fachir, A.M., Gerakan Rakyat untuk Perubahan, Pembelajaran dari Timur Tengah. Makalah disampaikan pada Pertemuan Kelompok Ahli, diselenggarakan oleh P2K2 ASPASAF, Bandung, pp. 11, 2011.

[7] Muawanah, Teguh Supriyanto., Pandangan Dunia Pengarang dan Konteks Sosial "Rumah Tanpa Jendela" Karya Asma Nadia. On Line Available: http://journal.unnes.ac.id/sju/index.php/seloka.

[8] Zahra, Silmi Lathifah., Pencerita dan Teknik Penceritaan dalam Novel Al-Karnak Karya Naguib Mahfudz. On Line Available: http://lib.ui.ac.id/file?file=digital/20308416-S42516Pencerita\%20dan.pdf.

[9] Nazir, Moh., Metode Penelitian. Jakarta: Galia Indonesia, 1985.

[10] Al-Jayyar, Madchat., An-Nashshu al-Adabiy min Mandzuri al-Ijtima'i. Dar al-Wafa, Kairo, 2005.

[11] Swingewood, Alan, The Sociology of Literature. London: Paladin, 1972.

[12] Machfoudz, Najib., Layali Alfu Lailah. Cetakan ke-5. Dar Syuruq: Kairo, 2014.

[13] Al-Baththuthiy, Mahir., Ar-Riwayah Al-Umm Alfu Lailah wa Lailah wal-Adab Al-'Alamiyyah. Maktabah Al-Adab: Kairo, 2005. 